\title{
OUT OF REACH
}

THE POETRY OF PHILIP LARKIN 
Also by Andrew Swarbrick

THE ART OF OLIVER GOLDSMITH (editor)

PHILIP LARKIN: The Whitsun Weddings and The Less Deceived

T. S. ELIOT: Selected Poems 


\section{Out of Reach}

\section{The Poetry of \\ Philip Larkin}

ANDREW SWARBRICK

Macmillan Education 
ISBN 978-0-333-59661-6 ISBN 978-1-349-24061-6 (eBook)

DOI 10.1007/978-1-349-24061-6

(C) Andrew Swarbrick 1995

Softcover reprint of the hardcover 1st edition 1995

All rights reserved. For information, write:

Scholarly and Reference Division,

St. Martin's Press, Inc., 175 Fifth Avenue,

New York, N.Y. 10010

First published in the United States of America in 1995

ISBN 978-0-312-12545-5

Library of Congress Cataloging-in-Publication Data

Swarbrick, Andrew.

Out of reach : the poetry of Philip Larkin / Andrew Swarbrick.

p. $\mathrm{cm}$.

Includes bibliographical references and index.

ISBN 978-0-312-12545-5

1. Larkin, Philip-Criticism and interpretation. I. Title.

PR6023.A66Z87 1995

$821^{\prime} .914-\mathrm{dc} 20$ 
For Anne, Tom, Jo and William 


\section{Contents}

Preface ix

Acknowledgements $\quad$ xi

1 Philip Larkin 1

2 The Early Poems 17

3 The Less Deceived 43

$4 \quad$ Larkin in the Movement 69

5 The Whitsun Weddings 92

6 High Windows 122

$7 \quad$ Larkin's Identities 154

$\begin{array}{ll}\text { Notes } & 175\end{array}$

$\begin{array}{ll}\text { Select Bibliography } & 188\end{array}$

$\begin{array}{ll}\text { Index } & 198\end{array}$ 


\section{Preface}

This book has been written in the conviction that Philip Larkin's poetry is important to us. It aims to present Larkin as more adventurous and challenging than we are used to recognising, and to rebut both the old charges of genteel parochialism and the new charges of ideological incorrectness. Although it takes account of recent biographical material, it is not simply an interpretation of the poems by way of the life. Indeed, as this study shows, the relationship between the two is in Larkin's case especially problematic. The focus of this study is on the poems and the rhetorical strategies which make them, in John Bayley's words, 'both wholly accessible and completely mysterious' (in the London Review of Books, 5-18 May 1983).

The book is organised around Larkin's separately published collections for the benefit of readers unfamiliar with the Collected Poems. Nevertheless, since this is a study of the whole poetic oeuvre (with some attention given to his two novels, Jill and A Girl in Winter), wide reference is made to poems not collected by Larkin in his four volumes. In these cases, references are given to Anthony Thwaite's edition of the Collected Poems. I have also been able to include previously unpublished material from Larkin's manuscript notebooks.

My earlier guide to Larkin in the Master Guide series published by Macmillan offered an explicatory account of some of his poems, and students in search of a basic introduction are directed there; I have taken the liberty, in the interim, of changing my mind on some points of interpretation. My hope is that this present book will prove of interest to the general reader and to the specialist alike.

I am grateful to the literary executors and Trustees of the Philip Larkin Estate for permission to consult and publish material lodged in the Philip Larkin Archive at the University of Hull Brynmor Jones Library, and to publish an extract from Larkin's correspondence with Barbara Pym. I owe particular debts to the Hull University Archivist, Brian Dyson; to Andrew Motion and Anthony Thwaite for commenting on a draft version of this book; to Stephen Regan who, as an anonymous reader, made many valuable suggestions during its preparation; to the staff of the Bodleian Library, Oxford, 
especially in the Department of Western Manuscripts; to the staff of Oxford Central Library; and to Susan Ward for bibliographical assistance. All errors remain my own.

Part of the first chapter appeared as 'Larkin: First and Final Drafts', Poetry Review, vol. 83, no. 4 (Winter 1993/94) pp. 50-53.

ANDREW SWARBRICK 


\section{Acknowledgements}

The author and publishers wish to thank the following for permission to use copyright material:

Carcanet Press Ltd for excerpts from 'Rejoinder to a Critic', 'Limited Achievement' and 'Remembering the Thirties' by Donald Davie from Collected Poems, 1990.

Jonathan Clowes Ltd on behalf of the author and Random House UK Ltd for an excerpt from 'Something Nasty in the Bookshop' by Kingsley Amis, reprinted as 'A Bookshop Idyll' in Collected Poems 1944-79, Hutchinson, 1979. Copyright (c) 1956 Kingsley Amis.

Faber \& Faber Ltd and Farrar Straus and Giroux, Inc. for excerpts from 'Party Politics', 'Ugly Sister', 'Love, we must part now', 'Blizzard', 'Waiting for breakfast', 'An April Sunday brings the snow', 'Modesties', 'To Failure', 'Strangers', 'Best Society', 'Oils', 'Fiction and the Reading Public', 'Water', 'A Study of Reading Habits', 'The Whitsun Weddings', 'Home is so Sad', 'Talking in Bed', 'Love', 'Dockery and Son', 'An Arundel Tomb', 'The Large Cool Store', 'Reference Back', 'Toads Revisited', 'The Old Fools', 'The Building', 'Money', 'High Windows', 'This Be The Verse', 'Vers de Sociéte', 'MCMXIV', 'The Dance', 'The Life with a Hole in it', 'Sad Steps', 'Show Saturday', 'The Explosion', 'Aubade', 'Love Again', 'The Winter Palace' and 'Continuing to Live' from Collected Poems by Philip Larkin. Copyright (C) 1988, 1989 by the Estate of Philip Larkin.

The Marvell Press for excerpts from 'Born Yesterday', 'Dry-Point', 'Deceptions', 'Next, Please', 'Poetry of Departures', 'Toads', 'Spring' and 'Wires' from The Less Deceived by Philip Larkin.

Quotations from Larkin's unpublished manuscripts held in the Philip Larkin Archive at the Brynmor Jones University Library, University of Hull, may not be reproduced without permission from the Estate of Philip Larkin. 
xii

Every effort has been made to trace all the copyright-holders, but if any have been inadvertently overlooked the publishers will be pleased to make the necessary arrangement at the first opportunity. 